\title{
The Cenozoic western Svalbard margin: sediment geometry and sedimentary processes in an area of ultraslow oceanic spreading
}

\author{
Ingrid Marie Hasle Amundsen • Maria Blinova • \\ Berit Oline Hjelstuen • Rolf Mjelde • \\ Haflidi Haflidason
}

Received: 8 November 2010/ Accepted: 22 March 2011/Published online: 17 April 2011

(C) The Author(s) 2011. This article is published with open access at Springerlink.com

\begin{abstract}
The northeastern high-latitude North Atlantic is characterised by the Bellsund and Isfjorden fans on the continental slope off west Svalbard, the asymmetrical ultraslow Knipovich spreading ridge and a 1,000 m deep rift valley. Recently collected multichannel seismic profiles and bathymetric records now provide a more complete picture of sedimentary processes and depositional environments within this region. Both downslope and alongslope sedimentary processes are identified in the study area. Turbidity currents and deposition of glacigenic debris flows are the dominating downslope processes, whereas mass failures, which are a common process on glaciated margins, appear to have been less significant. The slide debrite observed on the Bellsund Fan is most likely related to a 2.5-1.7 Ma old failure on the northwestern Barents Sea margin. The seismic records further reveal that alongslope current processes played a major role in shaping the sediment packages in the study area. Within the Knipovich rift valley and at the western rift flank accumulations as thick as $950-1,000 \mathrm{~m}$ are deposited. We note that oceanic basement is locally exposed within the rift valley, and that seismostratigraphic relationships indicate that fault activity along the eastern rift flank lasted until at least as recently as 1.5 Ma. A purely hemipelagic origin of the sediments in the rift valley and on the western rift flank is unlikely. We suggest that these sediments, partly, have been sourced from the western Svalbard-northwestern Barents Sea margin and into the Knipovich Ridge rift valley before
\end{abstract}

I. M. H. Amundsen - M. Blinova $(\varangle) \cdot$ B. O. Hjelstuen ·

R. Mjelde $\cdot$ H. Haflidason

Department of Earth Science, University of Bergen, Allegt 41,

5007 Bergen, Norway

e-mail: maria.blinova@geo.uib.no continuous spreading and tectonic activity caused the sediments to be transported out of the valley and westward.

Keywords Svalbard margin - Ultraslow spreading ridge · Trough mouth fans - Glaciations - Sedimentary processes

\section{Introduction}

The northern North Atlantic (Fig. 1) provides a region to study Cenozoic variations in ocean circulation, erosion, sedimentary processes and depositional environments in relations to tectonic events. The prominent Mid-Atlantic spreading ridge (Fig. 1) stretches for a distance of about $1,800 \mathrm{~km}$ through this part of the Atlantic Ocean and has over the last 55 million years shaped the NorwegianGreenland Sea into its present configuration. Through its development, the ridge affected sediment distribution and source areas (Skogseid and Eldholm 1989; Eldholm et al. 1994; Bruvoll et al. 2009). The Fram Strait and the Greenland-Scotland Ridge (Fig. 1), which limit the Norwegian-Greenland Sea towards north and south, represent significant gateways that during their Miocene opening and subsidence (Engen et al. 2003; Stoker et al. 2005) influenced oceanic circulation and depositional processes on both regional and global scale.

The continental margin off west Svalbard and the ultraslow Knipovich spreading ridge is the focus of this study (Figs. 1,2). The availability of multichannel seismic transects, stretching from the continental shelf and across the Knipovich Ridge, now make it possible to get a more complete picture of a shallow to deep sea depositional system. The seismic profiles, in addition to bathymetric records, also document the structural setting and sedimentary record within a rift valley in much larger detail 


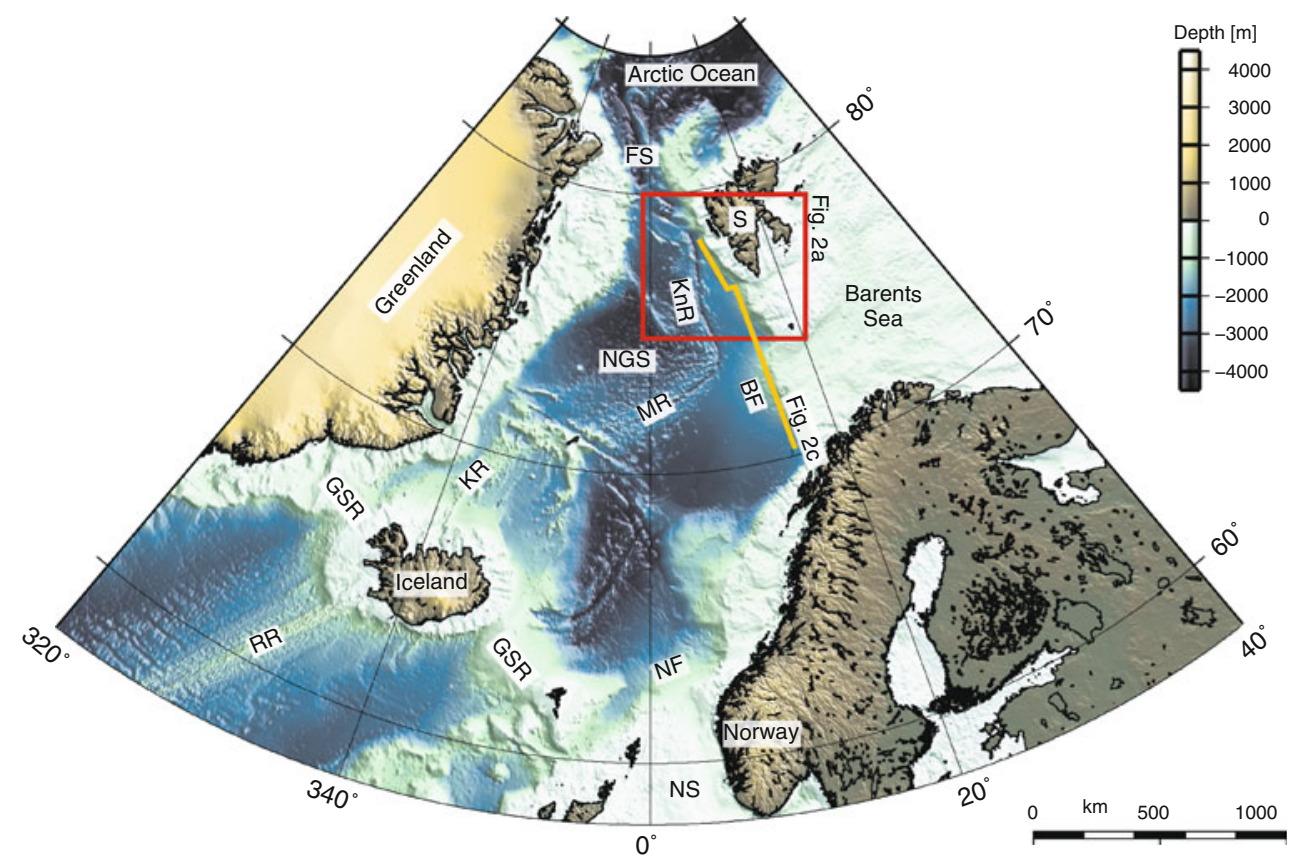

Fig. 1 Bathymetric map of the northern North Atlantic. Red box indicates study area. Yellow line represents position of geoseismic profile shown in Fig. 2c. BF Bjørnøya Fan, FS Fram Strait, GSR

than previously possible. The objectives of this paper is thus to: (1) establish a seismic stratigraphy for the sedimentary succession within the study area, (2) describe rift valley structures and sediment infill, (3) map out the sediments on the western flank of the Knipovich Ridge, (4) study seismic facies in order to identify sedimentary processes and in which places along the margin each of these processes are active, and (5) extend our knowledge on processes and depositional environments on glacialdominated continental margins.

\section{Background}

The opening of the northern North Atlantic (Fig. 1) occurred at the Paleocene-Eocene transition and took place in two stages, reflecting the change from a three- to twoplate configuration (e.g. Talwani and Eldholm 1977). During the first stage the region between Greenland and Svalbard (Fig. 1) did not open but moved along a continent-continent mega-shear zone. In the early Oligocene, the relative plate motion changed to a more east-westerly trend. This caused a northward opening of the Greenland Sea, first by continental extension and finally by sea floor spreading along the Knipovich Ridge (e.g. Mosar et al. 2002).

The Knipovich Ridge (Fig. 1), which is characterised by a 1,000-2,000 m deep rift valley and a sea floor depth ranging between 2,500 $\mathrm{m}$ and 3,800 $\mathrm{m}$, has been classified as an ultraslow spreading ridge (Dick et al. 2003). An important
Greenland-Scotland Ridge, KnR Knipovich Ridge, $K R$ Kolbeinsey Ridge, $M R$ Mohns Ridge; NGS Norwegian-Greenland Sea, NS North Sea, $N F$ North Sea Fan, $R R$ Reykjanes Ridge, $S$ Svalbard

characteristic of ultraslow spreading ridges is that their axes are made up of a series of linked magmatic and amagmatic accretionary segments. The rift valley of the Knipovich Ridge is no exception to this trend; it is segmented into extensional basins bounded by narrow, volcanically active and tectonically modified axial highs (Crane et al. 2001).

The spreading direction along the Knipovich Ridge is NNW-SSE, which is highly oblique to the rift axis. At present, the spreading rates along the Knipovich Ridge are slower in the north than in the south; estimated at 11.2 and $12.3 \mathrm{~mm} /$ year (full rates), respectively (Dick et al. 2003). Kandilarov et al. (2008) have shown that the Knipovich Ridge spreading rates have varied between 11 and $16 \mathrm{~mm} /$ year (full rates) through time. The magnetic anomalies generated around the Knipovich Ridge are diffuse. This is probably related to factors such as high heat flow and sediment loading (Engen et al. 2003). We note, however, that Anomalies 5 (9.8 Ma; Cande and Kent 1995), 6 (19.6 Ma) and $7(24.6 \mathrm{Ma})$ have been identified in a distance between c. 50 and $150 \mathrm{~km}$ from the Knipovich Ridge rift valley (Fig. 2a) (Engen et al. 2008; Kandilarov et al. 2008, 2010).

The continental slope off west Svalbard is characterised by Late Plio-Pleistocene fan complexes (e.g. Vorren et al. 1998). These fans have been deposited in front of troughs on the continental shelf (Fig. 2a) and they are strongly related to the glaciation history of the Barents Sea-Svalbard region. Recently, it has been suggested that the growth of the Barents Sea-Svalbard ice sheet have occurred in three stages (Knies et al. 2009): (1) An initial stage, between 


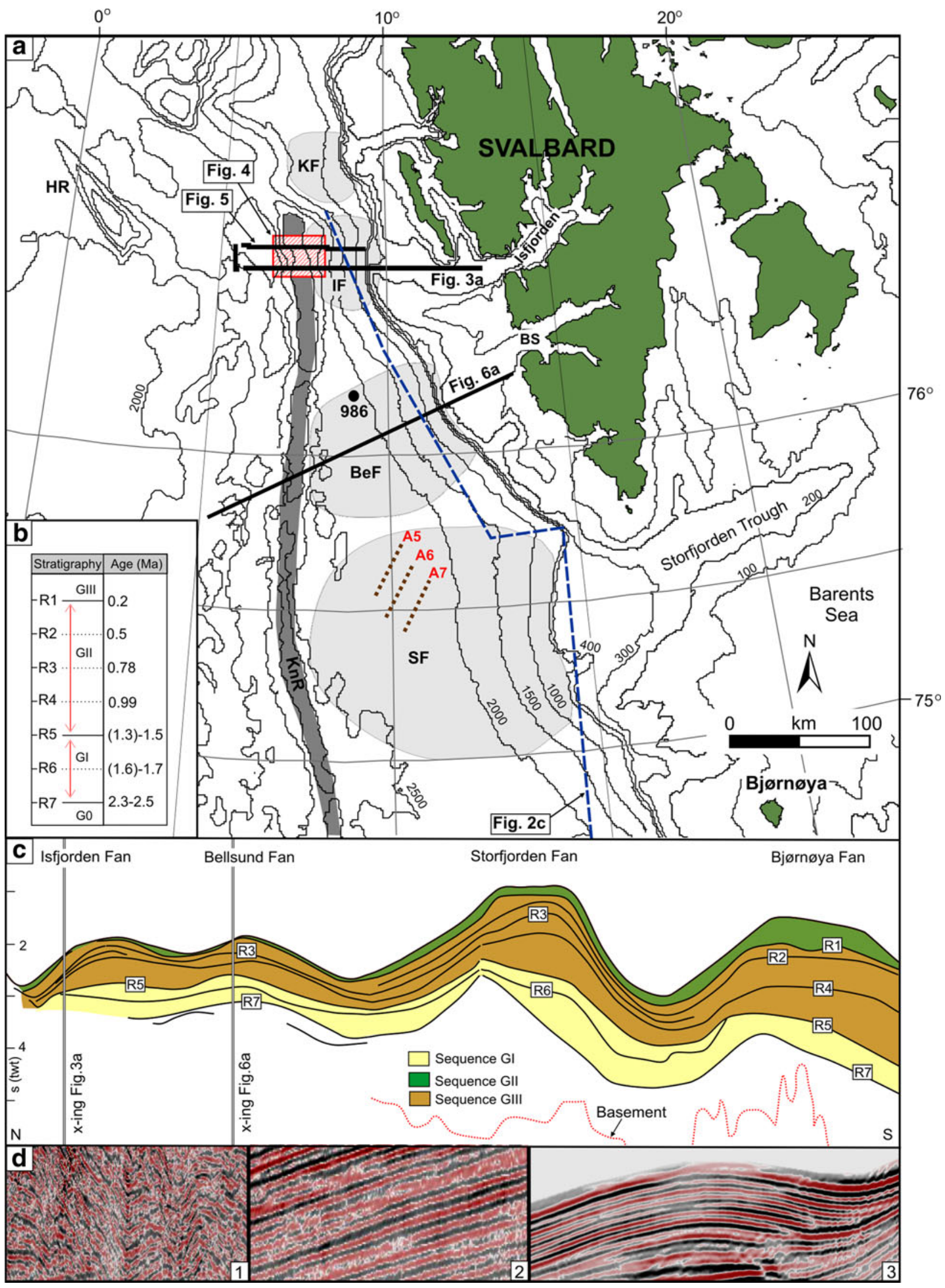


४Fig. 2 a Study area. Location of interpreted MCS profiles are shown by black lines, EM300 bathymetric coverage is outlined by red box, trough mouth fans are shown by a light grey colour, whereas the position of the Knipovich Ridge (KnR) rift valley is indicated by a dark grey zone. Positions of magnetic anomalies (A5-A7), shown by brown stippled lines, are from Kandilarov (2010). Blue stippled line show location of geoseismic profile shown in c. Bathymetry in meters. Figure location shown in Fig. 1. BS Bellsund, BeF Bellsund Fan, $H R$ Hovgaard Ridge, IF Isfjorden Fan, KF Kongsfjorden Fan, $S F$ Storfjorden Fan. b Seismic sequence stratigraphy (Faleide et al. 1996) and ages (Butt et al. 2000) used in this study. R1-R7: Identified sequence boundaries; G0-GIII: Identified sequences. c Interpreted seismic transect from the Barents Sea-Svalbard margin. R1-R7: Identified sequence boundaries. Crossing with seismic profiles in Figs. 3a and 6a are shown by grey lines. Profile location in Fig. 1 and a. Figure modified from Faleide et al. (1996). d Examples of main seismic facies in the study area. (1) Chaotic facies (slide debrites), (2) Parallel facies (glacimarine/hemipelagic sediments), (3) Migrating/ Mounded facies (contourites)

3.6 Ma and 2.4 Ma, with mountain and coastal glaciations, (2) a transition phase, between $2.4 \mathrm{Ma}$ and $1.0 \mathrm{Ma}$, where the Barents Sea-Svalbard ice sheet periodically extended onto the continental shelf, and (3) a final phase after 1.0 Ma, with repeated ice sheet advances to the shelf edge.

\section{Data and methods}

This work is based on 2D multichannel seismic (MCS) profiles and bathymetric records collected by the University of Bergen in 1999 and 2004 (Figs. 2a, 3, 4, 5, 6). The EM300 bathymetric records were acquired by R/V G.O. Sars in 2004 and cover about $1,500 \mathrm{~km}^{2}$ of the Knipovich Ridge (Fig. 2a). The EM300 data were processed using a grid size of $50 \times 50 \mathrm{~m}$. The seismic profiles have a total length of $500 \mathrm{~km}$. The main focus in this study will be the MCS profiles that stretch from the continental shelf to the deep ocean off Isfjorden and Bellsund (Fig. 2a).

The MCS data were acquired with a $3 \mathrm{~km}$ long streamer, containing 240 recording groups with $12.5 \mathrm{~m}$ spacing. The recording was done using $3 \mathrm{~Hz}$ low (18 db/octave) and $180 \mathrm{~Hz}$ high ( $72 \mathrm{db} /$ octave) cut filters. A tuned airgun array composed of 7 airguns as source was used throughout the survey. The shot-point interval performed was $50 \mathrm{~m}$ whereas the sampling interval and recording length were $2 \mathrm{~ms}$ and $12 \mathrm{~s}$ (two-way travel time [twt]), respectively. The vessel speed during acquisition was $4.5 \mathrm{kt}$. The seismic data set was processed in 2004 by the Russian
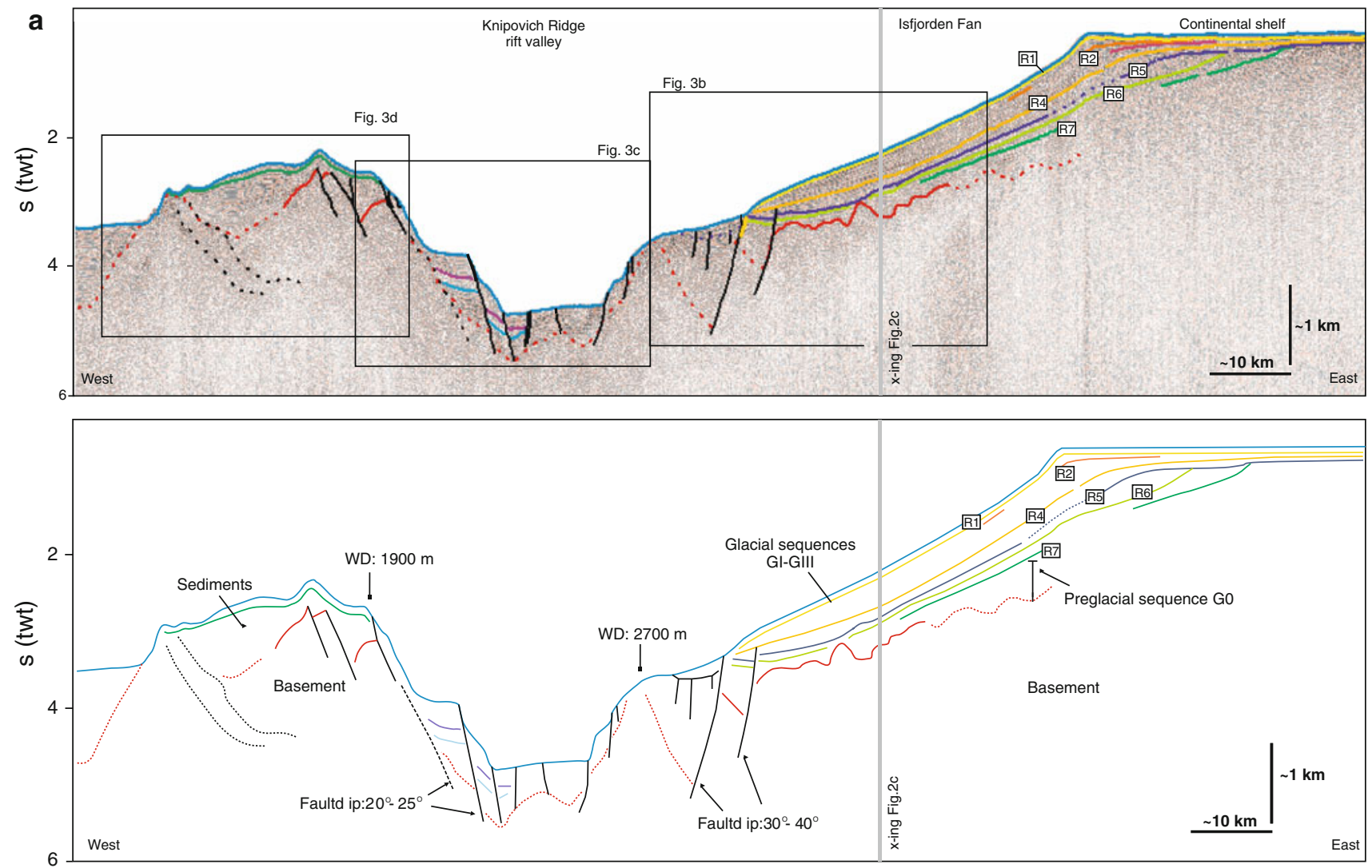

Fig. 3 a MCS transect from off Isfjorden. Interpreted sequence boundaries, R1-R7, are shown. WD Water depth. Profile location in Fig. 2a. b Seismic example from the eastern ridge flank, showing fault patterns and the distal part of the Isfjorden Fan system. R1-R7 Interpreted sequence boundaries. Profile location in a. c Sediment distribution and fault pattern within, and at the flanks, of the Knipovich Ridge rift valley. Profile location in a. d Sediment distribution and fault configuration west of the Knipovich Ridge rift valley. Profile location in a 

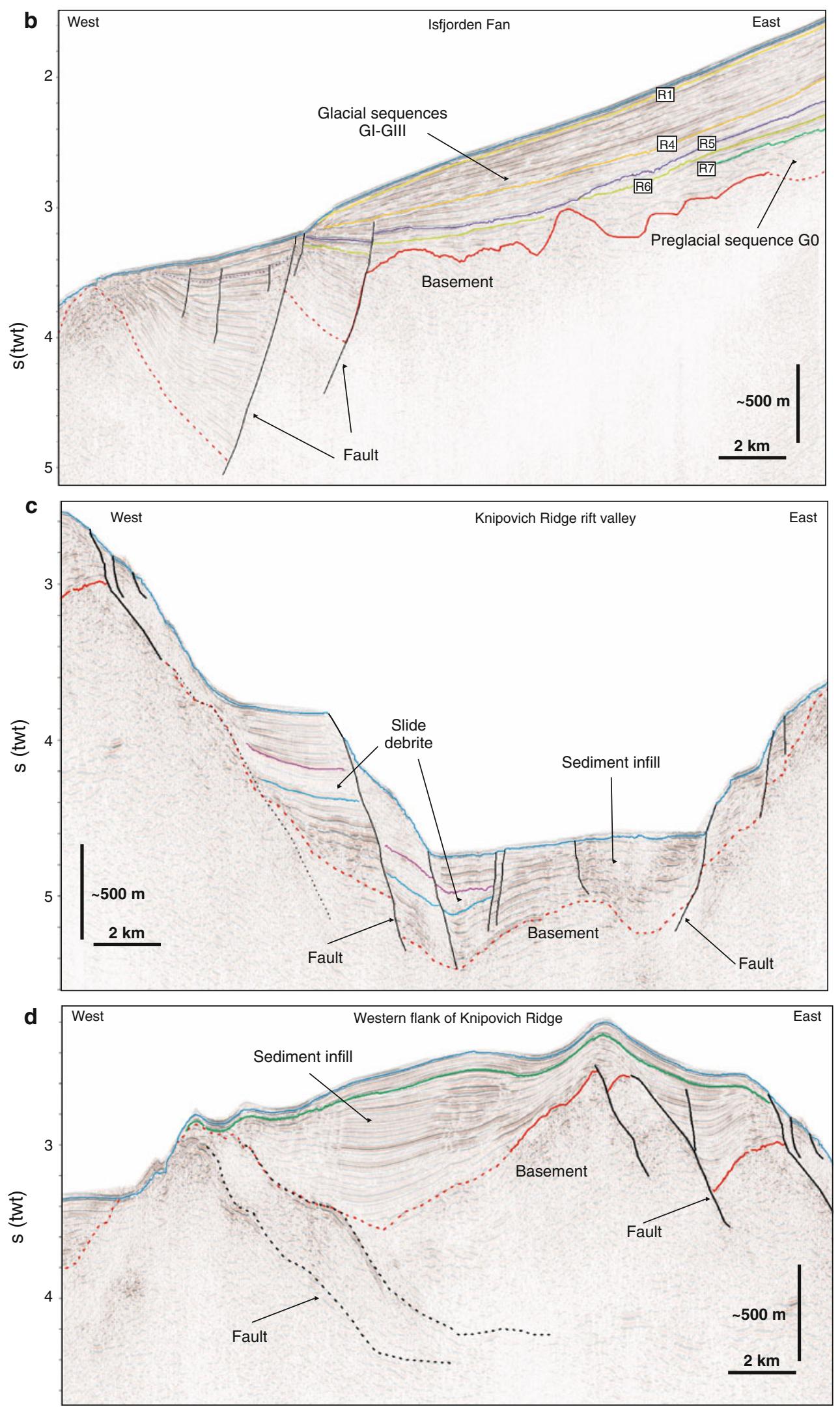

Fig. 3 continued 


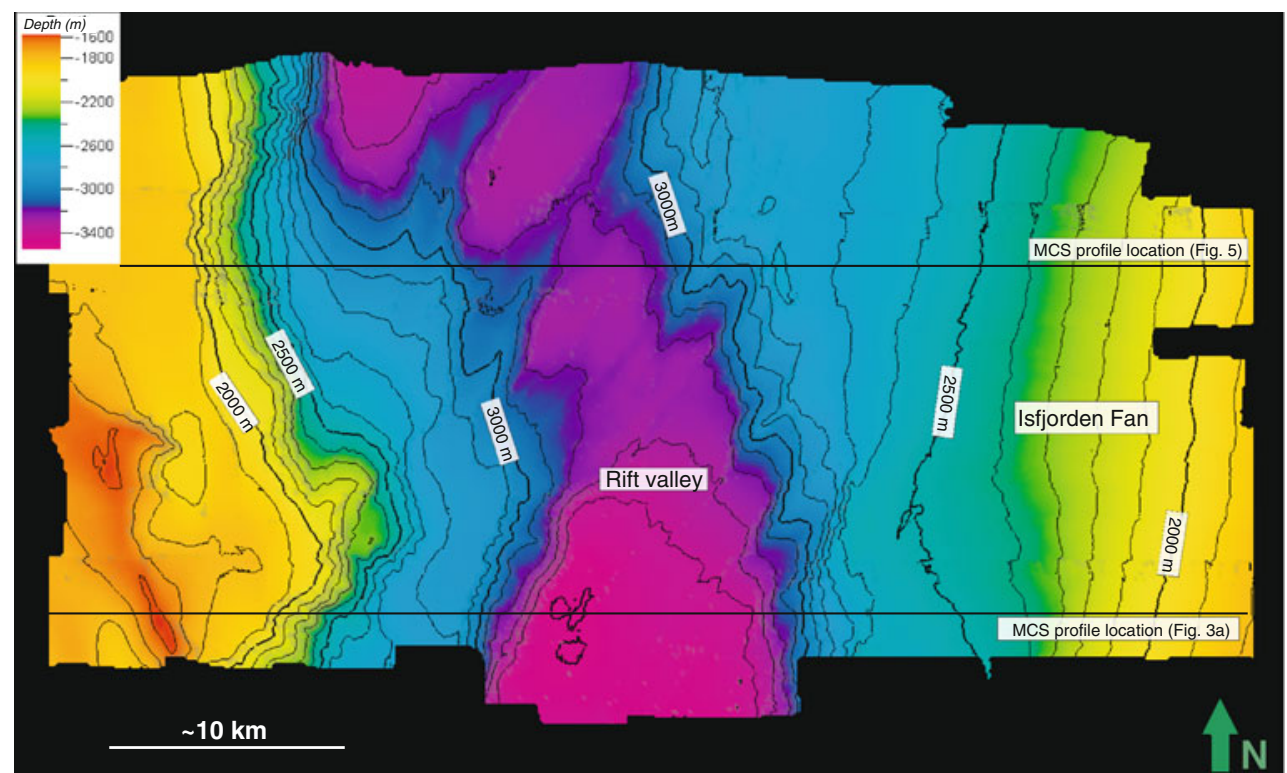

Fig. 4 EM300 bathymetric record showing details in the seabed surface of the Knipovich Ridge rift valley. Contours are shown by black lines and represent intervals of $100 \mathrm{~m}$. Location in Fig. 2a

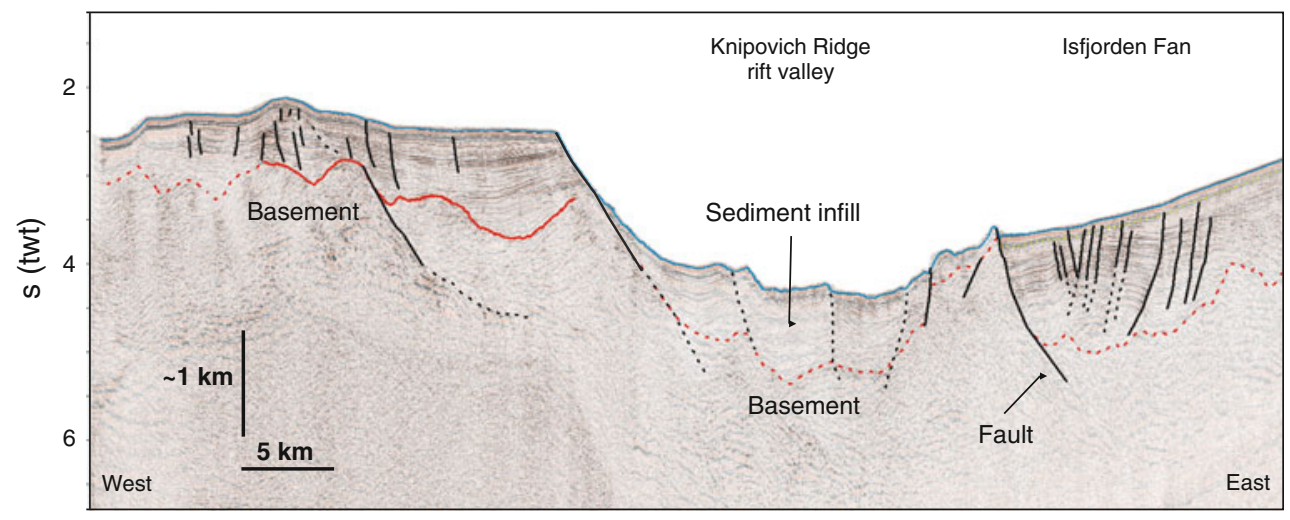

Fig. 5 Sediment distribution and fault-pattern characteristic along the Knipovich Ridge rift valley off Isfjorden. Profile location in Fig. 2a

company Sevmorgeo, following a standard workflow for seismic processing.

The processed MCS seismic profiles have a satisfactory signal-to-noise ratio for seismic interpretation. The profiles have a dominant frequency spectrum of $40 \mathrm{~Hz}$ and $30 \mathrm{~Hz}$ in their upper and lower parts, respectively (Amundsen 2008). By using an interval velocity of $\sim 1.7 \mathrm{~km} / \mathrm{s}$ (Kandilarov et al. 2008) the vertical resolution is thus about $10 \mathrm{~m}$ for the upper sediment layers. For the lower part of the sedimentary succession the vertical resolution is reduced to $\sim 48 \mathrm{~m}$, assuming a velocity of $\sim 5.7 \mathrm{~km} / \mathrm{s}$ (Ljones et al. 2004). Petrel v. 2007.1.1, from Schlumberger, was the primary software used for the interpretation of the seismic profiles. For conversion to sediment thicknesses and depths in metres a velocity of $1,800 \mathrm{~m} / \mathrm{s}$ has been used throughout the paper.
The MCS profiles in this study have been tied to the interpreted seismic profiles which Faleide et al. (1996) applied in their establishment of a regional stratigraphical framework for the entire Barents Sea-Svalbard margin (Fig. 2c). Based on seismic correlation to wells, Faleide et al. (1996) also added a chronology to their seismostratigraphy. The chronostratigraphy has later been revised by Butt et al. (2000), based on analyses of ODP Site 986 (Fig. 2b). As our MCS profiles cross the interpreted seismic profiles by Faleide et al. (1996) (Figs. 2c, 3a, 6a) a well constrained seismostratigraphy is obtained for our seismic data base. The seismostratigraphy encompasses four main sedimentary sequences (G0-GIII) bounded by sequence boundaries R7-R1 (Fig. 2b), where the R7 sequence boundary represents the change from mountain ice sheets to continental shelf extending ice sheets. 


\section{Results}

The seismic tie to the established seismostratigraphy along the Barents Sea-Svalbard margin infer that most of the sediments deposited on the western Svalbard continental slope are very young, i.e. of Late Pliocene and Pleistocene age (Figs. 2c, 3a, 6a). The identified preglacial sequence in the seismic profiles drapes the basement relief and is characterised by parallel reflectors on the upper continental slope, whereas sub-parallel reflectors and a hummocky seismic facies are observed downslope.

The sub-sequence that is bounded by reflectors $\mathrm{R} 7$ and R6 contains parallel reflectors and off Isfjorden this sub-sequence shows a westward thinning. Further south on the margin the R7-R6 sub-sequence comprises a chaotic seismic pattern (Figs. 2d, 6a, 6b). The subsequence is, in this region, showing a thickening from $135 \mathrm{~m}$ near the shelf edge to $610 \mathrm{~m}$ at the middle slope before thinning again to $125 \mathrm{~m}$ on the lower slope (Fig. 6a).

The upper sedimentary succession on the continental slope, i.e. the sediments deposited between Reflector R6 (Figs. 3b, 6b) and the seabed are commonly characterised by parallel and sub-parallel reflectors that display medium to high amplitudes (Fig. 2d). A migrating seismic pattern is however observed in the sub-sequence bounded by reflectors R6 and R5 off Bellsund (Fig. 6b). Reflector R5 defines a prominent unconformity, termed URU in previous studies (e.g. Solheim et al. 1996), that is observed all along the studied continental margin. We also note that both Reflector R5 and Reflector R6, which hold ages around $1.5 \mathrm{Ma}$, are intersected by faults nearby the ridge axis (Fig. 3b).

Rift valley: structural setting and sedimentary records

Well defined terraces surround the Knipovich Ridge rift valley. These half-grabens comprise thick sediment layers and the bounding faults are deeply rooted into oceanic basement (Figs. 3a, b). The faults are dipping towards the ridge axis. Both the fault pattern and the topographical relief around the rift valley are asymmetric (Figs. 3, 4). Comparing the water depth on either sides, the rift mountains east of the rift valley are located at c. 2,700 metres below seafloor (mbsf) while the rift mountains on the western side are lying at c. 1,900 mbsf (Fig. 3a). Further, the faults on the eastern side of the rift valley have dips between c. $30^{\circ}$ and c. $40^{\circ}$, whereas faults on the western valley flank have dips between 20 and $25^{\circ}$.
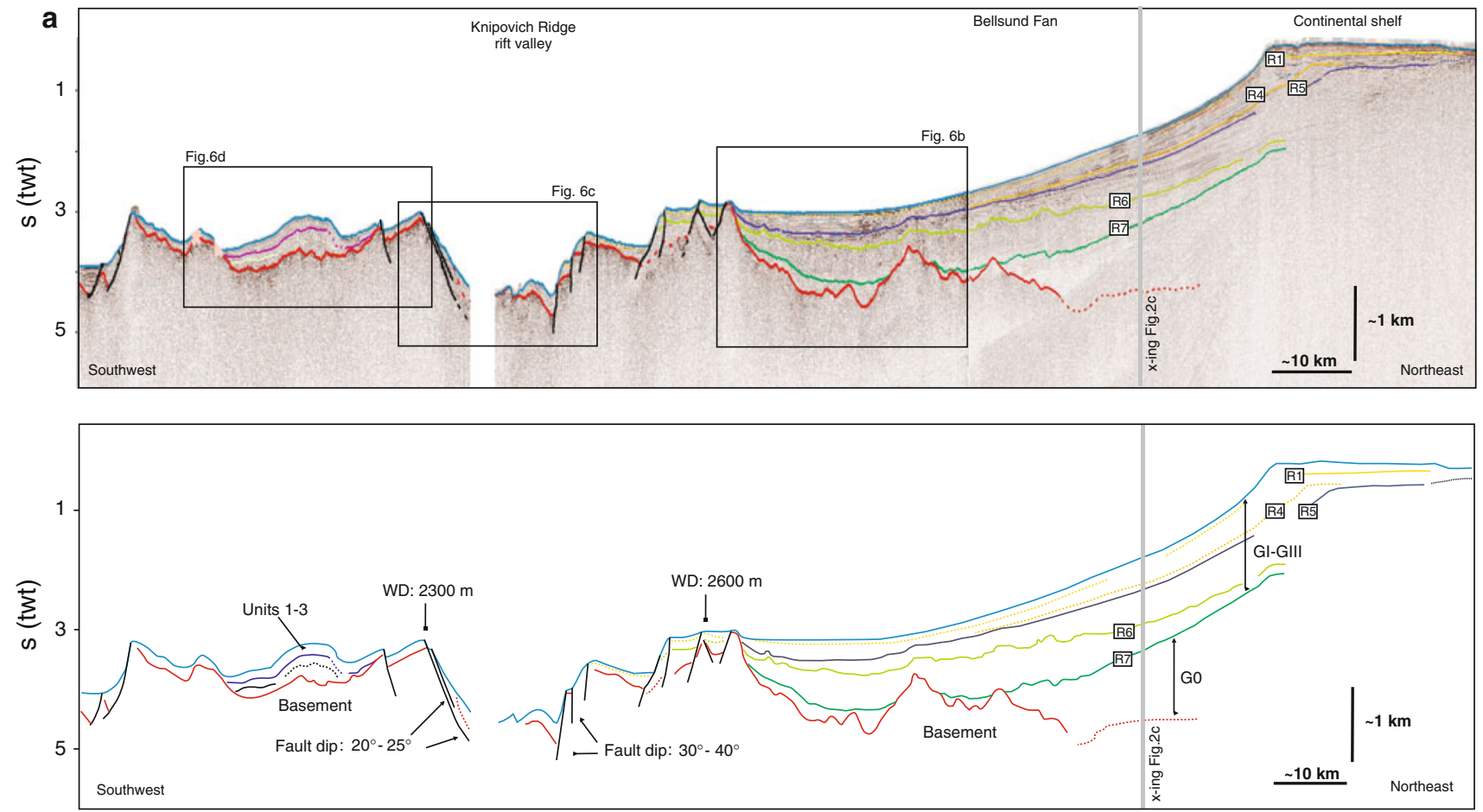

Fig. 6 a Sediment distribution and faulting characteristics along the Bellsund seismic transect. R1-R7 Interpreted sequence boundaries, G0-GIII Identified sequences, WD Water depth. Profile location in Fig. 2a. b MCS example from the lower continental slope off Bellsund, showing possible slide debrite in the GI sequence. Inserted is image showing possible current influenced sediments. R1-R7
Interpreted sequence boundaries, G0-GIII Identified sequences. Profile location in a. c Seismic example across the Knipovich Ridge, showing a rift valley almost empty of sediment. Profile location in a. d Seismic example showing seismic facies characteristics west of the Knipovich Ridge rift valley. Three distinct sedimentary units, $\mathrm{U} 1-\mathrm{U} 3$, are interpreted. Profile location in a 

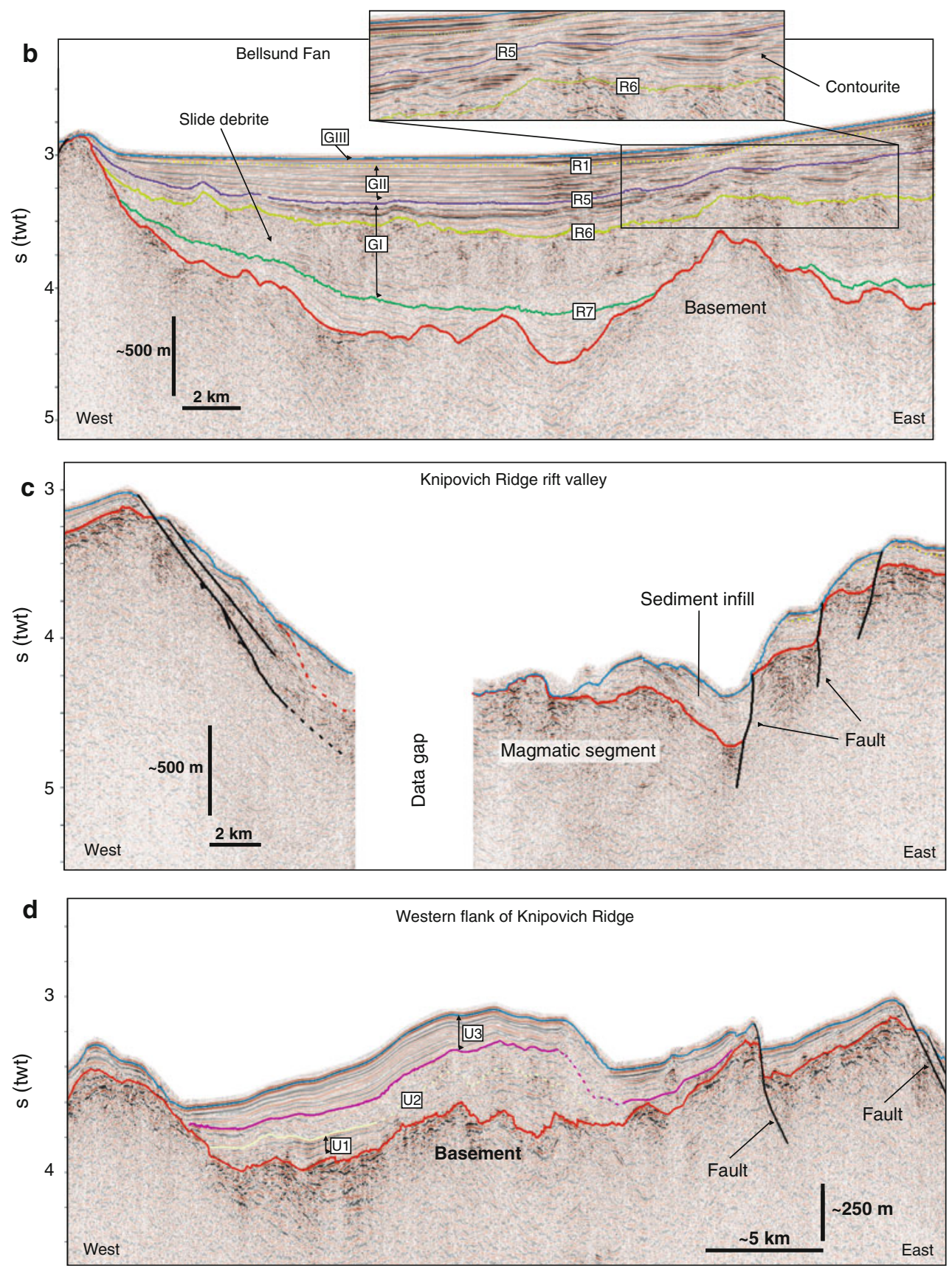

Fig. 6 continued

The bathymetric data acquired in the northern part of the study area (Figs. 2c, 4) clearly display the topography in this part of the rift valley, showing that the western and eastern side of the valley fit well together. The sea floor along the central part of the rift valley is flat and is lying at a water depth of $3,400 \mathrm{~m}$. The valley is filled in with a sedimentary succession that reaches a maximum thickness of $\sim 350 \mathrm{~m}$ in the centre of the valley and which increase to $\sim 650 \mathrm{~m}$ and $\sim 550 \mathrm{~m}$ at the western and eastern parts, respectively (Fig. 3c). The rift valley deposits rest conformably upon the basement surface and are commonly characterized by medium to high amplitude, parallel to sub-parallel reflectors (Fig. 2d). An acoustically transparent sediment unit is, however, observed in this acoustically well laminated sedimentary succession. This unit can be traced westwards up into the terraces located at this side of the valley, reaching a maximum thickness of $\sim 160 \mathrm{~m}$ (Fig. 3c).

In the northernmost MCS profile off Isfjorden (Fig. 2a) the rift valley is filled by a sedimentary section that reaches 
a maximum thickness of $950 \mathrm{~m}$ (Fig. 5). We note that the rift valley comprises a set of faults, intersecting both the sedimentary succession and the oceanic basement. The rift valley sediments are characterised by reflectors that appear to be laterally extensive across the entire width of the valley, noting that the reflectors in the middle and eastern part of the valley display lower amplitudes compared to the western side.

Further south along the Knipovich Ridge, i.e. off Bellsund, the rift valley seems to have a thinner accumulation of sediments compared to observations off Isfjorden. We note that oceanic basement is exposed in the centre of the valley (Fig. 6c). The largest accumulation of sediments is found on the eastern side of the valley, where the deposits reach a maximum thickness of $\sim 330 \mathrm{~m}$. This succession consists of eastward dipping sub-parallel strata in its upper part and chaotic layering in its lower part. Even though a section of data is missing, it appears that an up to $250 \mathrm{~m}$ thick sediment wedge has been deposited also at the western side of the rift valley in this region.

\section{Western flank of Knipovich Ridge}

In the northern part of the study area extensive faulting at the west flank of the Knipovich Ridge has created half-grabens in which an up to $900-1,100$ m thick sediment succession have accumulated (Figs. 3a, d). These faults appear to be growth faults, along where sediments have been deposited contemporaneously with the fault movement. We note that the sedimentary package contains parallel to sub-parallel reflectors that locally are intersected by faults. The reflectors are commonly of low to medium intensity. High amplitude reflectors are, however, locally observed.

A lens, having a maximum thickness of about $500 \mathrm{~m}$, is the most characteristic accumulation west of the spreading ridge in the southern part of the study area (Fig. 6d). The lens comprises three distinct units, termed units U1-U3. Unit U1 is characterised by parallel and sub-parallel reflectors and reaches a maximum thickness of c. $100 \mathrm{~m}$. Unit U2 is up to $250 \mathrm{~m}$ thick and displays an acoustic chaotic seismic pattern, whereas Unit U3 is an acoustic well-laminated unit that drapes Unit U2. We note that faults intersect the seabed and have displaced the sedimentary succession within this area (Fig. 6d).

\section{Discussion}

Since 3.5 Ma the studied region has been strongly influenced by the intensification of the glaciations within the area (Knies et al. 2009). A predominately glacial origin is therefore inferred for the entire continental slope sedimentary succession deposited between Reflector R7 and the seafloor.

Commonly, the sediment package deposited on the continental slope off west Svalbard is characterised by parallel to sub-parallel reflectors. However, in two places along the margin the seismic facies deviate from this trend (Fig. 6). The acoustic chaotic nature of sub-sequence R7-R6 on the Bellsund Fan (Fig. 6b) has been described in several studies (e.g. Schlüter and Hinz 1978; Eiken and Austegard 1987; Eiken and Hinz 1993). We follow the interpretation by Faleide et al. (1996) and suggest that mass movements have caused the chaotic seismic facies observed. There is, however, some ambiguity regarding the slide source area. We note that the R7-R6 sub-sequence on the Storfjorden Fan (Fig. 2b) shows the same chaotic seismic pattern as that on the Bellsund Fan (Faleide et al. 1996; Hjelstuen et al. 1996). Thus, the slide material on the Bellsund Fan might be related to a slide initiated on the Barents Sea-sourced Storfjorden Fan (Fig. 7a). Such a scenario would also explain the R7-R6 sub-sequence sediment composition as observed in ODP Site 986 (Fig. 2a), where low carbonate content, relatively high smectite content, and paleontological evidence indicate a Barents Sea origin (Forsberg et al. 1999). This interpretation is also supported by the foraminifera assemblage, indicating that the R7-R6 sediments nearby the Knipovich spreading ridge have been transported from shallower water depths (Solheim et al. 1998).

Within the R6-R5 sub-sequence off Bellsund we observe a wavy seismic pattern (Fig. 6b). This seismic facies is typical for contourite deposits (Faugères et al. 1999; Rebesco and Stow 2001). The presence of contourites at the western Svalbard margin has been reported in various studies (e.g. Eiken and Hinz 1993; Hustoft et al. 2009; Petersen et al. 2010). Based on mineralogical data from ODP sites 908 and 909 in the Fram Strait (Fig. 1), Wolf-Welling et al. (1996) suggested that the West Spitsbergen Current reached the Fram Strait episodically during Plio-Pleistocene (between 1.9 and 1.2 Ma). Thus, this influx of water masses along west Svalbard could have created environments for contourites to develop (Fig. 7b). We note that similar contourite-like deposits are not observed in the northern part of the study area, i.e. at the Isfjorden Fan.

Stacks of repeated units of glacigenic debris flows (GDFs), turbidites and water-lain sediments define the parallel and sub-parallel seismic facies which dominate the GI-GIII sequences (Figs. 2d, 3, 6) (Solheim et al. 1998; Forsberg et al. 1999; Escudia et al. 2000; Jessen et al. 2010). GDFs represent building blocks of trough mouth fan complexes, and is up to $200 \mathrm{~km}$ long, $<50 \mathrm{~m}$ thick and 1-40 km wide flows deposited only during shelf edge glaciations (King et al. 1998; Vorren et al. 1998; Nygård 

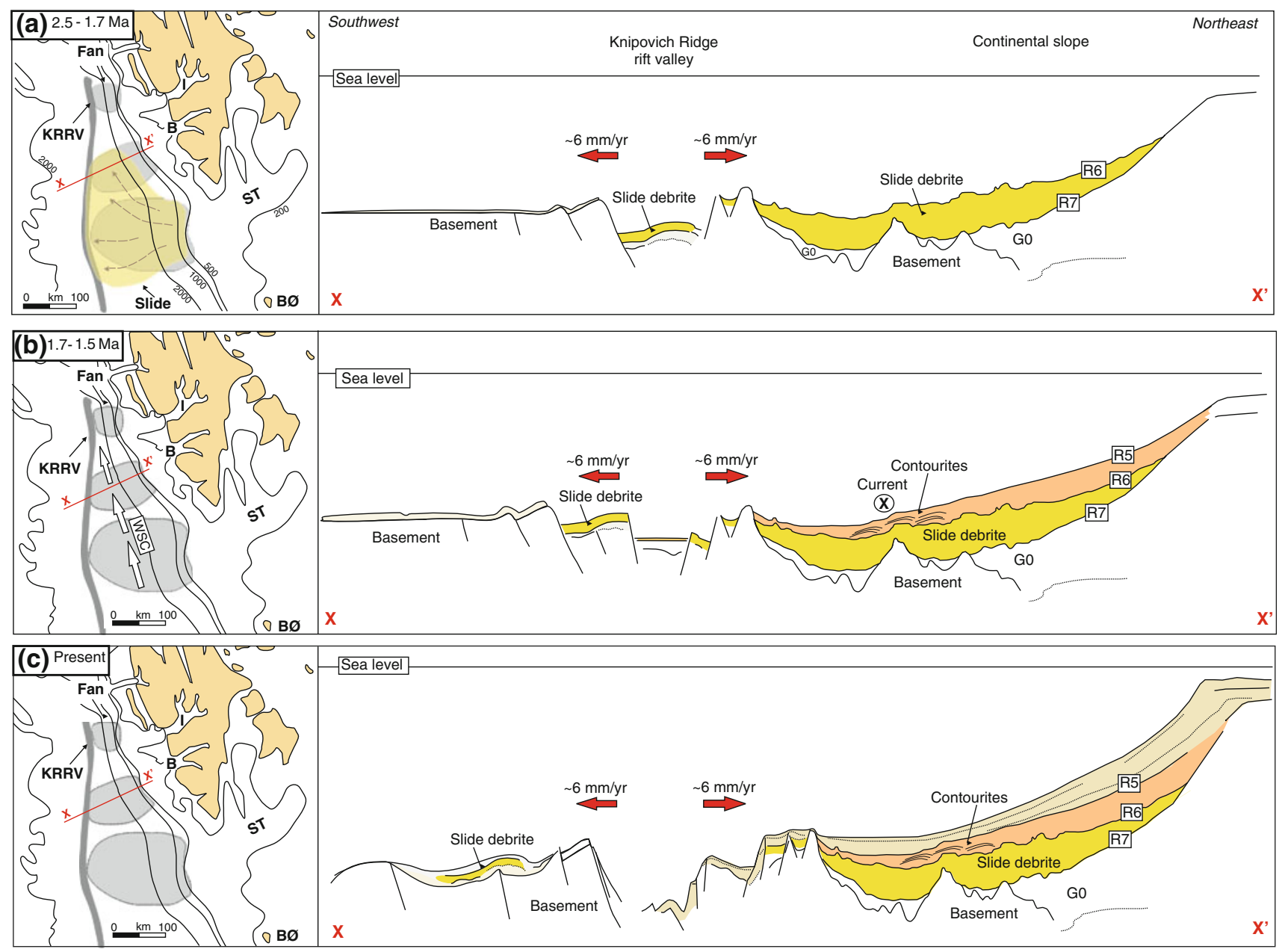

Fig. 7 Schematic maps and profiles showing margin configuration off western Svalbard at 2.5-1.7 $\mathrm{Ma}(\mathbf{a}), 1.7-1.5 \mathrm{Ma}(\mathbf{b})$ and at present (c). $I$ Isfjorden, $B$ Bellsund, $S T$ Storfjorden Trough, $B \emptyset$ Bear Island, KRRV Knipovich Ridge Rift Valley, WSC West Spitsbergen Current, R7-R5

et al. 2005). GDF deposition occurred frequently during the late Plio-Pleistocene time period along the Svalbard margin (Forsberg et al. 1999). Analyses of shallow sediment cores (Andersen et al. 1996), in addition to the $950 \mathrm{~m}$ long ODP Site 986 (Fig. 2a) (Forsberg et al. 1999), show that turbidity currents are a repetitive sediment process at the western Svalbard margin. The turbidites are typically some tens of $\mathrm{cm}$ in thickness, and it is inferred that turbidity currents have been the most significant down slope sediment transport mechanism during the last $1.0 \mathrm{Ma}$ within the study area (Shipboard Scientific Party 1996). Recent studies have shown that turbidites, commonly, are associated with submarine channels or canyons (Taylor et al. 2000; Ó Cofaigh et al. 2004; Haflidason et al. 2007). Such settings are not observed along the western Svalbard margin. Turbidity currents might, however, have been initiated in association with the larger-scale slide events within the study area, in a similar way as the turbidites generated during the Holocene Storegga Slide event on the
Identified sequence boundaries, G0-GIII Indentified sequences. Red arrows indicate spreading directions. Spreading rate $(\sim 6 \mathrm{~mm} / \mathrm{year})$ from Kandilarov et al. (2008)

Norwegian margin (Haflidason et al. 2004). Between the GDF and turbidite units, 40-50 cm thick layers of hemipelagic and meltwater deposits have accumulated in relation to interglacial and deglaciation periods, respectively (Jessen et al. 2010). We note that the parallel-subparallel seismic facies locally show a mounded seismic pattern, and account for that turbidites, GDFs, hemipelagic sediments and meltwater deposits might have been influenced by currents during and after deposition.

Only a thin sediment cover, reaching a maximum thickness of $330 \mathrm{~m}$, is observed in the rift valley off Bellsund at present (Fig. 6c). This could be due to magmatic intrusions and extrusions in an active part of the ridge, masking underlying sediment layers. In the rift valley off Isfjorden an up to $950 \mathrm{~m}$ thick sediment accumulation is identified (Fig. 3c). Similar thicknesses are deposited on the uplifted plateaus on the western side of the Knipovich Ridge (Figs. 3d, 5, 6d). We note that the evolved rift valley mountains on either side of the rift 
valley are at different water depths (Figs. 3a, 6a). The water depth difference is largest, about $800 \mathrm{~m}$, in the northern part of the study area. Similar observations have been made at the Knipovich-Mohns spreading ridge bend (Fig. 1; Bruvoll et al. 2009). Such depth differences might partly be related to the variability in sediment loading (Figs. 3a, 6a). Bruvoll et al. (2009) concluded, however, that tectonic activity has been the most significant factor in shaping the western and eastern rift mountains, and that sediment overburden has played a minor role. We note that the R6 and R5 sequence boundaries off Isfjorden are intersected by faults (Fig. 3b), indicating that tectonic activity within the region lasted until at least $1.5 \mathrm{Ma}$.

A purely hemipelagic origin of the sediments in the rift valley and on the wester rift flank are unlikely, considering the very slow sedimentation rates for such deposits compared to the relatively young age of the oceanic crust (Fig. 2a). From ODP Site 918, off southeast Greenland, hemipelagic depositional rates are estimated to about $2 \mathrm{~cm} / \mathrm{ka}$ (Solheim et al. 1998). Applying this rate to the $\sim 1,000 \mathrm{~m}$ thick unit on the North American tectonic plate off Isfjorden (Fig. 5), an age of about $50 \mathrm{Ma}$ is estimated for these deposits. If using a half-spreading rate of $5.5 \mathrm{~mm} /$ year (Kandilarov et al. 2008) we note, however, that the oceanic basement in this region is only about 3.5-4.5 million years old.

Eiken and Hinz (1993) suggested a possible currentcontrolled origin both for the sediments in the rift valley and for the sediments on the western flank of the Knipovich Ridge. We estimate depositional rates as high as $20-40 \mathrm{~cm} /$ ka for these sediments, and note that Laberg et al. (2001) found similar rates for current-related depositions on the Norwegian continental margin. Even though a presence of contourites cannot be proven for the successions in, and west, of the Knipovich Ridge off Bellsund, indications of current influence are observed in the upper sediment layers on the western ridge flank off Isfjorden (Figs. 3a, d, 5).

The high sedimentation rates for these deposits and the proximity to Svalbard may also indicate an easterly source area for the sediment accumulation in the rift valley and at the western rift flank. Bruvoll et al. (2009) suggested a depositional model in which sediments were transported from the SW Barents Sea continental slope into, and across, the Mohns-Knipovich spreading ridge bend (Fig. 1). This happened before the spreading, uplift, and rotation of the faults were significant enough to isolate the depositional basins on the North American tectonic plate from further sediment influx from the east.

This scenario, where sediments on the western side of the Knipovich spreading ridge were sourced from the east, may be reflected in the MCS-transect off Bellsund. A seismically chaotic sediment sequence, i.e. Unit U2, is here observed (Figs. 6a, d). This sequence may be indicative of slide debrites. Between c. $2.5 \mathrm{Ma}$ and $1.7 \mathrm{Ma}$ a failure occurred on the Storfjorden Fan (Hjelstuen et al. 1996) (Fig. 7a). The slide material from this failure was most likely transported north-northwestward towards the Bellsund area, and was deposited both on the continental slope and within the rift valley that existed at that time. As the sea floor spreading and tectonic activity continued the sediment in the rift valley was lifted out of the valley and transported westward with the North American tectonic plate with a rate of about $6 \mathrm{~mm} /$ year (Figs. 7b, c) .

The acoustic well-laminated pattern observed in the rift valley and at the western rift flank most likely represent similar deposits as those identified by groundtruthing on the western Svalbard continental slope (Andersen et al. 1996; Jessen et al. 2010), i.e. turbidites and GDFs, that had their source area at the Svalbard margin, and hemipelagic and meltwater deposits. As stated above, contour-controlled currents have probably also transported sediments into the study area; in addition to that they performed reworking on already deposited sediments.

\section{Summary and conclusions}

In this study, MCS profiles and bathymetric records from the marine realm off west Svalbard have been interpreted in order to analyse sedimentary processes, depositional environments and depositional history in a glacially influenced region. Two seismic facies dominate the seismic profiles interpreted: (1) Acoustic chaotic facies, related to slide debrites and (2) acoustic well-laminated facies, composed of parallel and sub-parallel reflectors, which represent turbidites, GDFs, hemipelagic sediments and melt-water deposits. Observation of mounded seismic patterns suggests that contour-controlled currents have influenced the sedimentation.

At the continental slope off west Svalbard the Isfjorden and Bellsund fans were built during the Late Plio-Pleistocene time period. Trough mouth fan complexes are common features at high latitude continental margins (Nielsen et al. 2005), and during the period of active fan development along the Svalbard margin turbidity currents and deposition of GDFs were common sedimentary processes. No larger-scale slides are observed on the Isfjorden Fan, and the slide material identified on the Bellsund Fan is most likely related to a 2.5-1.7 Ma old failure event on the Storfjorden Fan. Thus, it seems that slide processes have played a less significant role in the study area than along other glaciated margin segments, as for instance the Norway-Barents Sea margin (e.g. Evans et al. 2005; Solheim et al. 2005; Hjelstuen et al. 2007). Periodic inflow of the West Spitsbergen Current caused contourites to form on the lower continental slope off Svalbard in the time period 
between 1.7 and 1.5 Ma. Formation of contourites reflect present and past ocean current systems and are not restricted to glacial regions, but occur in a varity of high and low latitude geological settings (Laberg et al. 2005; Stoker et al. 2005; Rebesco et al. 2008).

The continental slope off Svalbard is bounded westward by the ultraslow Knipovich spreading ridge. The MCS profiles analysed, cross the spreading ridge and also the western rift flank, thus this study is one of the first to provide a detailed picture on sedimentary records within such structural settings. The Knipovich Ridge is characterised by a deep rift valley that contains up to $950 \mathrm{~m}$ of sediments, and which is bounded by faults having dips of $20-40^{\circ}$. We note, however, that oceanic basement is exposed within the rift valley off Bellsund. This is probably related to recent magmatic activity in this part of the spreading ridge. The large sediment thicknesses on young oceanic crust within, and east, of the rift valley, suggest another origin than purely hemipelagic sedimentation. Acoustic seismic facies characteristics indicate that the sediments, in addition to hemipelagic deposits, most likely are composed of turbidites, GDFs, meltwater deposits and slide debrites. As along the western Svalbard continental slope, currents might both have transported sediments into the area and reworked sediments during their deposition. We further suggest that some of the sediments accumulated at the western rift flank, as the identified slide debrite, have their origin from the western Svalbard-northwestern Barents Sea continental margin.

Acknowledgments We acknowledge the captains and the crews on R/V Håkon Mosby and R/V G.O. Sars, as well as engineers from the Department of Earth Science, UiB, for all help during data collection. We thank the Norwegian Petroleum Directorate for permission to conduct the surveys, and for partial funding. Sevmorgeo is acknowledged for MCS processing and Alexandre Kandilarov for technical assistance. The editor and two anonymous reviewers contributed substantially to improve the paper.

Open Access This article is distributed under the terms of the Creative Commons Attribution Noncommercial License which permits any noncommercial use, distribution, and reproduction in any medium, provided the original author(s) and source are credited.

\section{References}

Amundsen IMH (2008) Interpretation of multichannel seismic data from the western Svalbard margin. Unpublished master of science thesis, Department of Earth Science, University of Bergen, $98 \mathrm{pp}$

Andersen ES, Dokken TM, Elverhøi A, Solheim A, Fossen I (1996) Late quaternary sedimentation and glacial history of the western Svalbard continental margin. Mar Geol 133:123-156

Bruvoll V, Breivik AJ, Mjelde R, Pedersen RB (2009) Burial of the mohn-knipovich ridge by the bear island fan: time constrains on tectonic evolution from seismic stratigraphy. Tectonics 28: TC4001. doi:10.1029/2008TC002396

Butt FA, Elverhøi A, Solheim A, Forsberg CF (2000) Deciphering late cenozoic development of western Svalbard Margin from ODP Site 986 results. Mar Geol 169:373-390

Cande SC, Kent DV (1995) Revised calibration of the geomagnetic polarity timescale for the late cretaceous and cenozoic. J Geophys Res 100(B4):6093-6095

Crane K, Doss H, Vogt P, Sundvor E, Cherkashov G, Poroshina I, Joseph D (2001) The role of the Spitsbergen shear zone in determining morphology, segmentation and evolution of the Knipovich Ridge. Mar Geophys Res 22(3):153-205

Dick HJB, Lin J, Schouten H (2003) An ultraslow-spreading class of ocean ridge. Nature 426(6965):405-412

Eiken O, Austegard A (1987) The tertiary orogenic belt of West Spitsbergen: seismic expressions of the offshore sedimentary basins. Norw J Geol 67:383-394

Eiken O, Hinz K (1993) Contourites in the Fram Strait. Sed Geol $82: 15-32$

Eldholm O, Myhre AM, Thiede J (1994) Cenozoic tectono-magmatic events in the North Atlantic: potential paleoenvironmental implications. In: Boulter MC, Fischer HC (eds) Cenozoic plants and climates of the Arctic, NATO ASI Ser. I27. Springer, Heidelberg, pp 35-55

Engen Ø, Eldholm O, Bungum H (2003) The Arctic plate boundary. J Geophys Res 108(B2):2075. doi:1029/2002JB001809

Engen $\varnothing$, Faleide JI, Dyreng TK (2008) Opening of the Fram Strait gateway: a review of plate tectonic constraints. Tectonophysics 450:51-69

Escudia C, Eittreim SL, Cooper AK, Nelson CH (2000) Morphology and acoustic character of the Antarctic Wiles Land turbidite systems: ice-sheet-sources versus river-sourced fans. J Sed Res 70:84-93

Evans D, Harrison Z, Shannon PM, Laberg JS, Nielsen T, Ayers S, Holmes R, Hoult RJ, Lindberg B, Haflidason H (2005) Palaeoslides and other mass failures of Pliocene to Pleistocene age along the Atlantic continental margin of NW Europe. Mar Pet Geol 22(9-10):1131-1148

Faleide JI, Solheim A, Fiedler A, Hjelstuen BO, Andersen ES, Vanneste K (1996) Late Cenozoic evolution of the western Barents Sea-Svalbard continental margin. Glob Planet Change 12:53-74

Faugères J-C, Stow DAV, Imbert P, Viana A (1999) Seismic features diagnostic of contourite drifts. Mar Geol 162:1-38

Forsberg CF, Solheim A, Elverhøi A, Jansen E, Channell JET, Andersen ES (1999) The depositional environment of the western Svalbard margin during the upper Pliocene and the Pleistocene; sedimentary facies changes at Site 986 . In: Raymo ME, Jansen E, Blum P, Herbert TD (eds) Proceedings of the ODP science research, vol 162, pp 233-246

Haflidason H, Sejrup HP, Nygård A, Mienert J, Bryn P, Lien R, Forsberg CF, Berg K, Masson D (2004) The Storegga Slide: architecture, geometry and slide development. Mar Geol 213:201-234

Haflidason H, de Alvaro MM, Nygård A, Sejrup HP, Laberg JS (2007) Holocene sedimentary processes in the Andøya Canyon system, north Norway. Mar Geol 246:86-104

Hjelstuen BO, Elverhøi A, Faleide JI (1996) Cenozoic erosion and sediment yield in the drainage area of the Storfjorden Fan. Glob Planet Change 12:95-117

Hjelstuen BO, Eldholm O, Faleide JI (2007) Recurrent Pleistocene mega-failures on the SW Barents Sea margin. Earth Planet Sci Let 258:605-618

Hustoft S, Bunz S, Mienert J, Chand S (2009) Gas hydrate reservoir and active methane- venting province in sediments on $<20 \mathrm{Ma}$ 
young oceanic crust in the Fram Strait, offshore NW-Svalbard. Earth Planet Sci Let 284:12-24

Jessen SP, Rasmussen TL, Nielsen T, Solheim A (2010) A new Late Weichselian and Holocene marine chronology for the western Svalbard slope 30,000-0 cal years BP. Quat Sci Rev 29:1301-1312

Kandilarov A, Mjelde R, Okino K, Murai Y (2008) Crustal structure of the ultra-slow spreading Knipovich Ridge, North Atlantic, along a presumed amagmatic portion of oceanic crustal formation. Mar Geophys Res 29(2):109-134

Kandilarov A, Landa H, Mjelde R, Okino K, Murai Y (2010) Crustal structure of the ultra- slow spreading Knipovich Ridge, North Atlantic, along a presumed segmented center. Mar Geophys Res 31:173-195

King EL, Haflidason H, Sejrup HP, Løvlie R (1998) Glacigenic debris flows on the North Sea trough mouth Fan during ice stream maxima. Mar Geol 152:217-246

Knies J, Matthiessen J, Vogt C, Laberg JS, Hjelstuen BO, Smelror M, Larsen E, Andreassen K, Eidvin T, Vorren T (2009) A new PlioPleistocene ice sheet model for the Svalbard/Barents Sea region. Quat Sci Rev 28:812-829

Laberg JS, Dahlgren T, Vorren TO, Haflidason H, Bryn P (2001) Seismic analyses of Cenozoic contourite drift development in the Northern Norwegian Sea. Mar Geophys Res 22:401-416

Laberg JS, Stoker MS, Dahlgren KIT, de Haas H, Haflidason H, Hjelstuen BO, Nielsen T, Shannon PM, Vorren TO, van Weering TCE, Ceramicola S (2005) Cenozoic alongslope processes and sedimentation on the NW European Atlantic margin. Mar Pet Geol 22:1069-1088

Ljones F, Kuwano A, Mjelde R, Breivik A, Shimamura H, Murai Y, Nishimura Y (2004) Crustal transect from the North Atlantic Knipovich Ridge to the Svalbard Margin west of Hornsund. Tectonophysics 378:17-41

Mosar J, Torsvik TH, BAT team (2002) Opening of the Norwegian and Greenland Seas: plate tectonics in Mid Norway since the Late Permian. In: Eide EA (ed) BATLAS-Mid Norway plate reconstructions atlas with global and Atlantic perspectives, Geological Survey of Norway, pp 48-59

Nielsen T, De Santis L, Dahlgren KIT, Kuijpers A, Laberg JS, Nygård A, Praeg D, Stoker MS (2005) A comparison of the NW European glaciated margin with other glaciated margins. Mar Pet Geol 22(9-10):1149-1183

Nygård A, Sejrup HP, Haflidason H, Bryn P (2005) The glacial North Sea Fan, southern Norwegian Margin: architecture and evolution from the upper continental slope to the deep-sea basin. Mar Pet Geol 22:71-84

Ó Cofaigh C, Dowdeswell JA, Evans J, Kenyon NH, Taylor J, Mienert J, Wilken M (2004) Timing an significance of glacially influenced mass-wasting in the submarine channels of the Greenland Basin. Mar Geol 207:39-54

Petersen CJ, Bünz S, Hustoft S, Mienert J, Klaeschen D (2010) Highresolution P-Cable 3D seismic imaging of gas chimney structures in gas hydrated sediments of an Arctic sediment drift. Mar Pet Geol 27:1981-1994

Rebesco M, Stow D (2001) Seismic expression of contourites and related deposits: a preface. Mar Geophys Res 22:303-308

Rebesco M, Camerlenghi A, Van Loon AJ (2008) Contourite research: a field in full development. In: Rebesco M, Camerlenghi A (eds) Contourites, Developments in Sedimentology 60. Elsevier, USA, pp 3-10

Schlüter HU, Hinz K (1978) The continental margin of WestSpitsbergen. Polarforschung 48:151-169

Shipboard Scientific Party (1996) Site 986. In: Jansen E, Raymo ME, Blum $\mathrm{P}$ et al (eds) Proceedings of the ODP init rep, vol 162, pp 287-343

Skogseid J, Eldholm O (1989) Vøring Plateau continental margin: seismic interpretation, stratigraphy, and vertical movements. In: Eldholm O, Thiede J, Taylor E et al (eds) Sci Res ODP 104:993-1030

Solheim A, Andersen ES, Elverhøi A, Fiedler A (1996) Late Cenozoic depositional history of the western Svalbard continental shelf, controlled by subsidence and climate. Glob Planet Change 12:135-148

Solheim A, Faleide JI, Andersen ES, Elverhøi A, Forsberg CF, Vanneste K, Uenzelmann-Neben G, Channell JET (1998) Late Cenozoic seismic stratigraphy and glacial geological development of the East Greenland and Svalbard-Barents Sea continental margins. Quat Sci Rev 17:155-184

Solheim A, Berg K, Forsberg CF, Bryn P (2005) The Storegga Slide complex: repetitive large scale sliding with similar cause and development. Mar Pet Geol 22:97-107

Stoker MS, Hoult RJ, Nielsen T, Hjelstuen BO, Laberg JS, Shannon PM, Praeg D, Mathiesen A, van Weering TCE, McDonnell A (2005) Sedimentary and oceanographic responses to early Neogene compression on the NW European margin. Mar Pet Geol 22(9-10):1031-1044

Talwani M, Eldholm O (1977) Evolution of the Norwegian-Greenland Sea. Geol Soc Am Bull 88(7):969-999

Taylor J, Dowdeswell JA, Kenyon NH, Whittington RJ, van Weering TCE, Mienert J (2000) Morphology and late Quaternary sedimentation on the North Faeroes slope and abyssal plain, North Atlantic. Mar Geol 168:1-24

Vorren TO, Laberg JS, Blaume F, Dowdeswell JA, Kenyon NH, Mienert J, Rumohr J, Werner F (1998) The NorwegianGreenland Sea continental margins: morphology and late quaternary sedimentary processes and environment. Quat Sci Rev 17:273-302

Wolf-Welling TCW, Cremer M, O'Connell S, Winkler A, Thiede J (1996) Cenozoic Arctic gateway paleoclimate variability: indications from changes in coarse-fraction composition. In: Thiede J, Myhre AM, Johnson GL, Ruddiman WF (eds) Proceedings of the ODP science research, vol 151, pp 515-568 